\title{
Growth of novel ceramic layers on metals via chemical and heat treatments for inducing various biological functions
}

\author{
Tadashi Kokubo* and Seiji Yamaguchi \\ Department of Biomedical Sciences, College of Life and Health Sciences, Chubu University, Kasugai, Japan
}

The present authors' systematic studies on growth of novel ceramic layers on Ti metal and its alloys by chemical and heat treatments for inducing bone-bonding bioactivity and some other biological functions are reviewed. Ti metal formed an apatite on its surface in a simulated body fluid, when heat-treated after exposure to strong acid solutions to form rutile surface layer, or to strong alkali solutions to form sodium titanate surface layer. Both types of Ti metal tightly bonded to the living bone. The alkali and heat treatment

OPEN ACCESS

Edited by:

Aldo R. Boccaccini,

University of Erlangen-Nuremberg,

Germany

Reviewed by:

Ilaria Cacciotti,

University of Rome Niccolò

Cusano, Italy

Oscar Castano,

Institute for Bioengineering of

Catalonia, Spain

${ }^{*}$ Correspondence:

Tadashi Kokubo

kokubo@isc.chubu.ac.jp

Specialty section:

This article was submitted to

Biomaterials, a section of the

journal Frontiers in Bioengineering

and Biotechnology

Received: 20 July 2015

Accepted: 13 October 2015

Published: 27 October 2015

Citation:

Kokubo T and Yamaguchi S (2015) Growth of novel ceramic layers on

metals via chemical and heat treatments for inducing various biological functions.

Front. Bioeng. Biotechnol. 3:176. doi: 10.3389/fbioe.2015.00176 was applied to the surface Ti metal of an artificial hip joint and successfully used in the clinic since 2007. The acid and heat treatments was applied to porous Ti metal to induce osteoconductivity as well as osteoinductivity. The resulting product was successfully used in clinical trials for spinal fusion devices. For the Ti-based alloys, the alkali and heat treatment was little modified to form calcium titanate surface layer. Bone-growth promoting $\mathrm{Mg}$, Sr, and $\mathrm{Zn}$ ions as well as the antibacterial $\mathrm{Ag}$ ion were successfully incorporated into the calcium titanate layer.

Keywords: bioactivity, osteoconduction, osteoinduction, Ti metal, Ti-based alloys, apatite, alkali and heat treatment, acid and heat treatment

\section{INTRODUCTION}

A considerable amount of material is needed to repair bone defects in both orthopedics and dentistry. Autogenous bone is the best bone substitute material in terms of compatibility with the surrounding tissue. However, only a small amount of bone can be harvested from the healthy part. Allogenic bone is the second choice, commonly results in side effects such as foreign body reaction and/or infection. Therefore, synthetic materials free of antigens or toxic impurities are obviously required.

Various kinds of synthetic materials have been used as bone substitutes, including organic polymers, ceramics, metals, and composites. However, most of them are encapsulated in a collagenous fibrous tissue so as to be isolated from living bone (Park and Lakes, 1992). This is a normal foreign body reaction that protects living tissue. However, because of this reaction, synthetic materials do not become stably fixed to the surrounding bone for a long period of time.

In contrast, certain kinds of ceramics such as Bioglass ${ }^{\circledR}$ in $\mathrm{Na}_{2} \mathrm{O}-\mathrm{CaO}-\mathrm{SiO}_{2}-\mathrm{P}_{2} \mathrm{O}_{5}$, glassceramic A-W-containing crystalline apatite and Wollastonite in $\mathrm{MgO}-\mathrm{CaO}-\mathrm{SiO}_{2}-\mathrm{P}_{2} \mathrm{O}_{5}$, sintered hydroxyapatite of the composition $\mathrm{Ca}_{10}\left(\mathrm{PO}_{4}\right)_{6}(\mathrm{OH})_{2}$, sintered $\beta$-tricalcium phosphate of the composition $3 \mathrm{CaO} \cdot \mathrm{P}_{2} \mathrm{O}_{5}$, and biphasic calcium phosphates composed of hydroxyapatite and $\beta$-tricalcium phosphate have all been found to bond to living bone without forming fibrous tissue around them. 
They are called "bioactive ceramics" and are already in clinical uses as important bone substitutes (Kokubo, 2008). However, their mechanical strength and fracture toughness are not as high as those of human cortical bone, so they cannot be used under load-bearing conditions.

Under load-bearing conditions, metallic materials such as stainless steel, Co-Cr-Mo alloys, titanium (Ti) metal, and its alloys are mainly used, because of their high mechanical strengths and superior corrosion resistances (Park and Lakes, 1992). However, even Ti metal and Ti-based alloys, which exhibit best biocompatibility among them, are also encapsulated by fibrous tissue and do not bond to living bone (Hacking et al., 2002). Their fixation also does not become stable for long period of time.

In order to confer bone-bonding bioactivity to the metallic materials, some bioactive ceramics such as hydroxyapatite have been coated on them using various techniques, such as plasma spraying, flame spraying, sputtering, sol-gel deposition, biomimetic method (Leeuwenburgh et al., 2008), and alternating soaking (Taguchi et al., 2001). However, the coated layer is not stable in the living body, because of its vulnerability to cracking, transformation, and degradation (Leeuwenburgh et al., 2008).

The present authors recently reported that certain metallic materials such as Ti metal and its alloys exhibit bone-bonding bioactivity when a certain kind of thin ceramic layer is grown on their surface via simple chemical and heat treatments. In the present paper, the recent results of our research on this subject are reviewed.

\section{BASIC CONCEPT FOR CONFERRING BONE-BONDING BIOACTIVITY TO METALS}

It was found by the present authors that Bioglass ${ }^{\circledR}$, glass-ceramic $\mathrm{A}-\mathrm{W}$ and sintered hydroxyapatite bond to living bone through an apatite layer that forms on their surfaces in the living body. In contrast, glass-ceramic $\mathrm{A}-\mathrm{W}(\mathrm{Al})$ containing crystalline apatite and wollastonite similar to glass-ceramic A-W, but added with a small amount of $\mathrm{Al}_{2} \mathrm{O}_{3}$, neither formed the apatite on its surface in the living body nor bonded to living bone. Consequetly, it was concluded that a material able to form the apatite on its surface in the living body is able to bond to living bone through the apatite layer, but a material unable to form the surface apatite does not bond to living bone (Kokubo and Takadama, 2006). Therefore, it is expected that even metallic materials will bond to living bone when their surfaces are modified such that they form the apatite on their surface in vivo.

Is it necessary that every metal subjected to different surface modifications should be implanted into animal bone defects to check for the apatite formation on their surfaces? This would require not only considerable cost and time but also the sacrifice of a great many animals.

We demonstrated that the apatite formation on the surfaces of Bioglass ${ }^{\circledR}$, glass-ceramic A-W and sintered hydroxyapatite in vivo can be reproduced, even in an acellular simulated body fluid (SBF) having ion concentrations almost equal to those of the human blood plasma. In contrast, glass-ceramic A-W(Al) did not form apatite on its surface in SBF nor bonded in the living body. This means that the apatite formation on a material in the living body can be evaluated in SBF without the need of animal experiments (Kokubo and Takadama, 2006).

The next problem was to determine the kind of material that effectively induces apatite formation in SBF. We found that certain simple metal oxide gels, such as $\mathrm{TiO}_{2}, \mathrm{ZrO}_{2}, \mathrm{Nb}_{2} \mathrm{O}_{5}$, and $\mathrm{Ta}_{2} \mathrm{O}_{5}$ form the apatite on their surfaces in SBF within a week (Li et al., 1994). Metallic materials are generally covered with a thin oxide layer. In view of this fact, it is expected that metallic materials based on $\mathrm{Ti}, \mathrm{Zr}, \mathrm{Nb}$, and $\mathrm{Ta}$ form the apatite on their surfaces in SBF, as well as in the living body, so as to be able to bond to living bone when their surfaces are appropriately modified.

\section{SURFACE MODIFICATION OF METALS}

Ti metal and its alloys are the most widely used type of material as implants in the orthopedic and dental fields among the metallic materials described above because of their better compatibility with living tissue. Therefore, various surface modifications were applied to Ti metal and its alloys for inducing bone-bonding bioactivity using various methods, including ion implantation (Armitage et al., 2007; Nayab et al., 2007; Rautray et al., 2010), electrochemical reaction (Suh, 2003; Bjursten et al., 2010; Shibata et al., 2010; Whiteside et al., 2010; Zhao et al., 2010; Diefenback et al., 2011; Xie et al., 2011; Minagar et al., 2013; Zhang et al., 2013; Zhou et al., 2014), and hydrothermal treatments (Dong et al., 2007; Park et al., 2007, 2010; Chen et al., 2009; Ueda et al., 2009; Zhang et al., 2010). However, these techniques require special equipment and are not readily applicable to large-scale medical devices of complicated or porous structure. In contrast with these techniques, chemical and heat treatments do not have such limitations.

Various kinds of chemical and heat treatments also have been applied to Ti metal and its alloys to induce apatite formation on their surfaces in SBF (Wang et al., 2002; Wu et al., 2004; Takeuchi et al., 2005; Zhao et al., 2005, 2008; Cooper et al., 2006; Lee et al., 2007; Liu et al., 2007; Zhou et al., 2007; Sugino et al., 2009; Karthega and Rajendran, 2010; Li et al., 2010; Turkan and Guden, 2010; Ferraris et al., 2011). However, few results in these studies have been considered in terms of the mechanism of the apatite formation and correlated with the in vivo bone-bonding bioactivity.

The following are systematic studies we conducted on chemical and heat treatments of Ti metal and its alloys for inducing apatite formation on their surfaces in SBF along with their correlation with in vivo bone-bonding bioactivity.

\section{SIMPLE CHEMICAL AND HEAT TREATMENTS OF TI METAL}

When a rectangular plate of Ti metal was soaked in an aqueous solution in which the $\mathrm{pH}$ was systematically changed from almost 0 to 14 by $\mathrm{HCl}$ or $\mathrm{NaOH}$ at $60^{\circ} \mathrm{C}$ for $24 \mathrm{~h}$, it formed micrometer-scale roughness, precipitating titanium hydride $\left(\mathrm{TiH}_{\mathrm{x}}\right)$ on its surface for the strong acid solutions $<1.1$ in $\mathrm{pH}$, 
and nanometer-scale roughness precipitating sodium hydrogen titanate $\left(\mathrm{Na}_{\mathrm{x}} \mathrm{H}_{2-\mathrm{x}} \mathrm{Ti}_{3} \mathrm{O}_{7}, 0<x<2\right)$ on its surface (Yamaguchi et al., 2009) for the strong alkali solutions higher than 13.6 in $\mathrm{pH}$, as shown in Figure 1.

Only the Ti metal soaked in the strong alkali solutions higher than 13.6 in $\mathrm{pH}$ formed the apatite on its surface in SBF within 3 days, as shown in Figure 1 (Pattanayak et al., 2012).

When the Ti metal was heat-treated at $600^{\circ} \mathrm{C}$ for $1 \mathrm{~h}$ after exposure to the solutions described above, no surface morphological change was observed on its surface as the result of the heat treatment. However, the titanium hydride was transformed into rutile $\left(\mathrm{TiO}_{2}\right)$, while the sodium hydrogen titanate was transformed into sodium titanate $\left(\mathrm{Na}_{2} \mathrm{Ti}_{6} \mathrm{O}_{13}\right)$ and rutile by the heat treatment. The Ti metals exposed to the solutions with intermediate $\mathrm{pH}$ values also precipitated the rutile on their surfaces by the heat treatment, as shown in Figure 2.

Among them, only the Ti metals heat-treated after exposure to the strong acid solutions $<1.1$ in $\mathrm{pH}$ or strong alkali solutions higher than 13.6 in $\mathrm{pH}$ formed the apatite on their surfaces in SBF within 3 days, as shown in Figure 2 (Pattanayak et al., 2012).

It is clear from these results that the apatite formation on Ti metal depends upon neither the specific surface roughness nor crystalline phase. When the zeta potential of the Ti metal heat-treated after exposure to the solutions is measured, it can be seen from Figure 3 that the apatite formation on the Ti metal is induced by the positive or negative surface charge (Pattanayak et al., 2012).

A positively charged surface might preferentially adsorb negatively charged phosphate ions in SBF. As the phosphate ions accumulate, its surface becomes negatively charged so as to combine with the positively charged calcium ions, forming an amorphous calcium phosphate. This calcium phosphate is metastable and eventually transforms into stable crystalline apatite, as shown in Figure 4 (Pattanayak et al., 2012).
In contrast, a negatively charged surface would be expected to first preferentially adsorb positively charged calcium ions. As the calcium ions accumulate, its surface becomes positively charged so as to combine with the negatively charged phosphate ions, forming an amorphous calcium phosphate and then the crystalline apatite (Kim et al., 2003).

This sequential adsorption of the phosphate and calcium ions was confirmed by X-ray photoelectron spectroscopy (XPS) (Takadama et al., 2001a) and transmission electron microscopic observation combined with energy dispersive X-ray analysis (Takadama et al., 2001b) of the surface of the Ti metal soaked in SBF for different periods of time, as well as for the Ti metal heat-treated after exposure to the strong acid or alkali solution (Pattanayak et al., 2012).

The positive surface charge of the Ti metal heat-treated after exposure to the strong acid solution might be explained as follows. The Ti metal becomes adsorbed with $\mathrm{Cl}^{-}$ions during the acid treatment. The $\mathrm{Cl}^{-}$ions remain even after the heat treatment, and are dissociated in SBF so as to produce a local acidic environment on the Ti metal. It has been reported that titanium oxide is positively charged in an acidic environment (Gold et al., 1989). Consequently, the surface of the Ti metal heat-treated after exposure to strong acid solution is positively charged.

The negative surface charge of the $\mathrm{Ti}$ metal heat-treated after exposure to the strong alkali solutions might be explained as follows. The sodium titanate on the surface of the Ti metal releases $\mathrm{Na}^{+}$ions via exchange with the $\mathrm{H}_{3} \mathrm{O}^{+}$ions in $\mathrm{SBF}$ so as to produce a local alkaline environment on the Ti metal. It has been reported that titanium oxide is negatively charged in an alkaline environment (Gold et al., 1989). Consequently, the surface of the Ti metal heat-treated after exposure to the alkali solution is negatively charged.

When the Ti metal is heat-treated after exposure to a neutral solution, it is not charged, since no charge is produced on
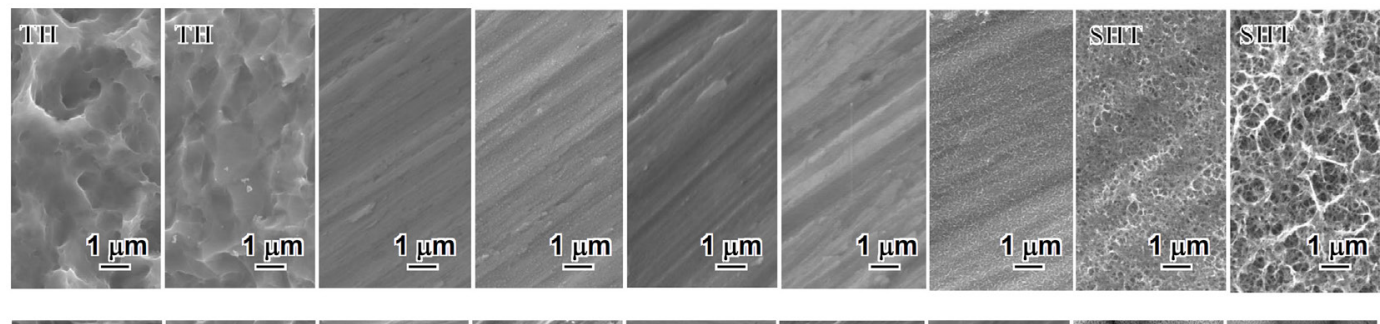

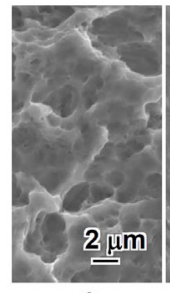

$\approx 0$

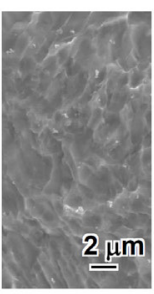

0.1
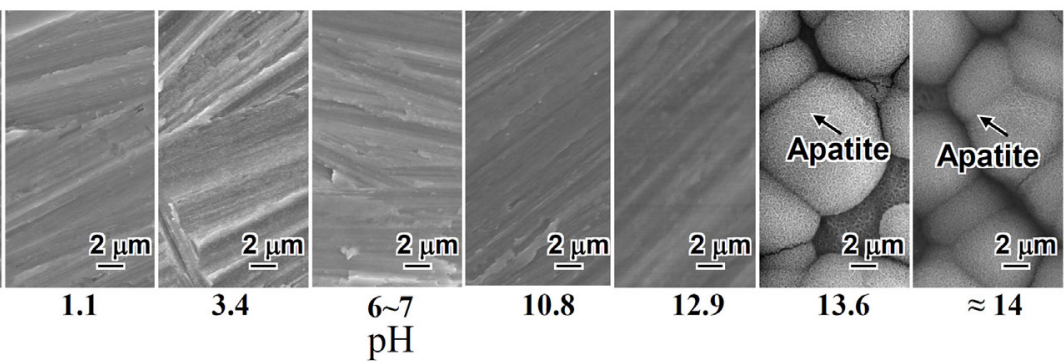

FIGURE 1 | SEM photographs of surfaces of Ti metal exposed to solutions with different pHs (top) and those of the same surfaces after soaking in SBF for 3 days (bottom). TH, titanium hydride; SHT, sodium hydrogen titanate. Reproduced from Pattanayak et al. (2012) with permission The Royal Society. 

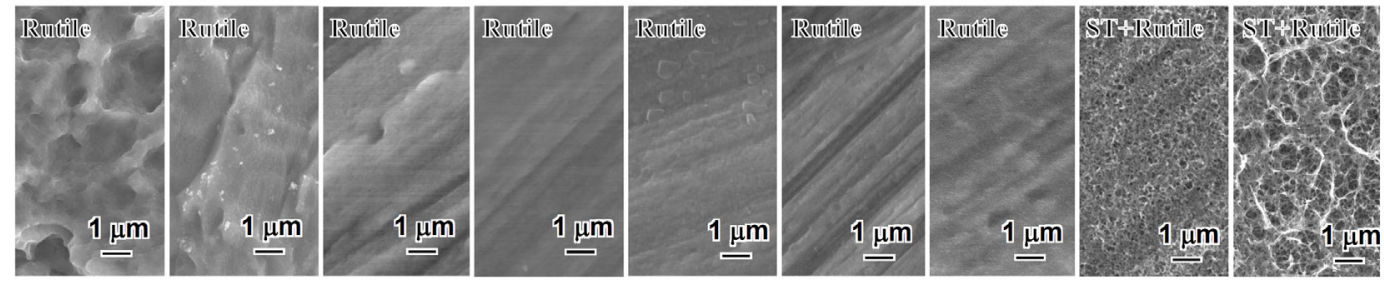

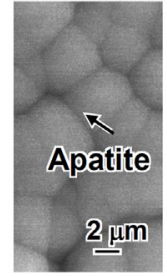

$\approx 0$

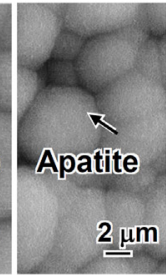

0.1

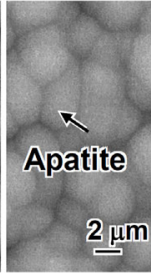

1.1

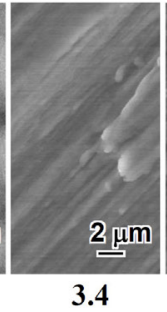

3.4
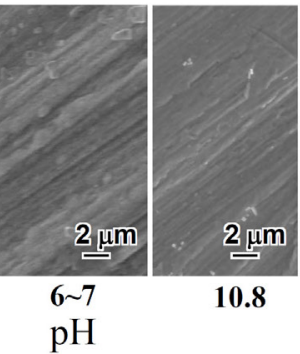

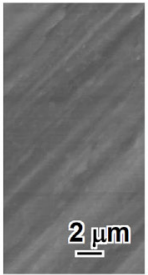

12.9

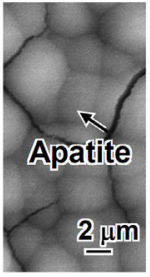

13.6

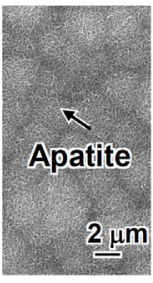

$\approx 14$

FIGURE 2 | SEM photographs of surfaces of Ti metal heat-treated after exposure to solutions with different pHs (top) and those of the same surfaces after soaking in SBF (bottom). ST, sodium titanate. Reproduced from Pattanayak et al. (2012) with permission The Royal Society.

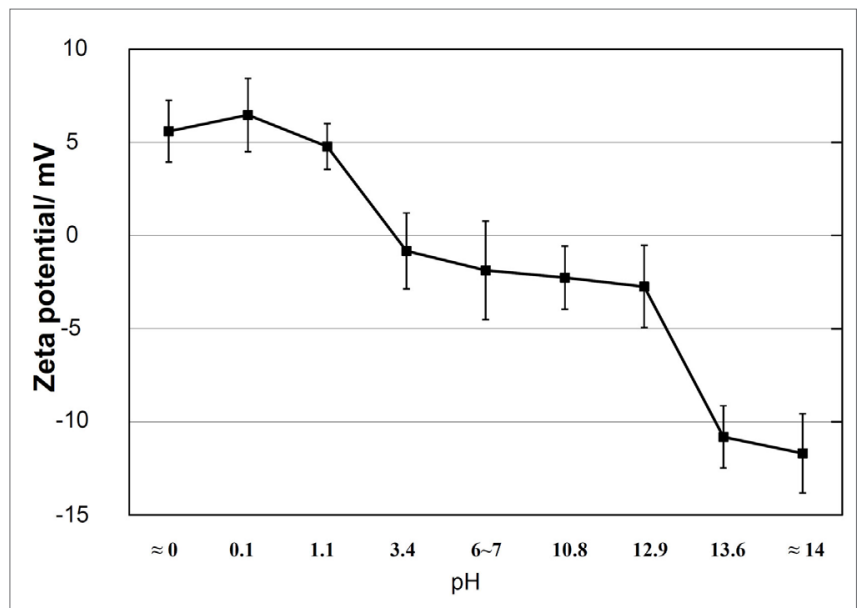

FIGURE 3 | Zeta potentials of Ti metal heat-treated after exposure to solutions with different $\mathbf{p H}$ values. Reproduced from Pattanayak et al. (2012) with permission The Royal Society.

its surface. When it is not heat-treated after exposure to the solution, it is not charged except after exposure to the strong alkali solutions, since an electrically insulating oxide layer is not produced on its surface except in the last case. As result, the apatite is not formed on the Ti metal surface in SBF in these cases except the last, as may be seen in Figures $\mathbf{1}$ and $\mathbf{2}$ (Pattanayak et al., 2012).

This dependence of the apatite formation on the Ti metal upon the $\mathrm{pH}$ of the exposed solution is valid for different kinds of acid and alkali solutions. For example, the Ti metal also forms the apatite on its surface in SBF when heat-treated at $600^{\circ} \mathrm{C}$ for $1 \mathrm{~h}$ after exposure to strong $66.3 \% \mathrm{H}_{2} \mathrm{SO}_{4} / 10.6 \% \mathrm{HCl}$ acid solution at $70^{\circ} \mathrm{C}$ for $24 \mathrm{~h}$ (Kokubo et al., 2010).
When the Ti metal subjected to the $\mathrm{H}_{2} \mathrm{SO}_{4} / \mathrm{HCl}$ acid and heat treatments was implanted into a rabbit tibia, it came into direct contact with the surrounding bone within 4 weeks, without any intervening fibrous tissue at the interface, as shown in Figure 5D. The metal became so tightly bonded to the bone that fracture did not occur at their interface but rather in the bone itself when tensile stress was applied to the interface. In contrast, Ti metals subjected to no treatment, only to the $\mathrm{H}_{2} \mathrm{SO}_{4} / \mathrm{HCl}$ acid treatment or only to the heat treatment at $600^{\circ} \mathrm{C}$, were encapsulated by fibrous tissue, as shown in Figures 5A-C (Kawai et al., 2012).

When the Ti metal plate heat-treated at $600^{\circ} \mathrm{C}$ after exposure to $5 \mathrm{M} \mathrm{NaOH}$ solution at $60^{\circ} \mathrm{C}$ for $24 \mathrm{~h}$ was implanted into a rabbit tibia, within 8 weeks it became bonded to the surrounding bone through an apatite layer that formed on the Ti metal surface, as shown in Figure 6 (Yan et al., 1997). When a rod of the same metal was implanted into the medullary canal of the rabbit femur, it became so tightly bonded to the surrounding bone within 12 weeks that it was not able to be extracted without accompanying bone fragments, as shown in Figure 7 (Nishiguchi et al., 2003).

These in vivo bone-bonding bioactivity findings of the $\mathrm{Ti}$ metals are consistent with the in vitro apatite formation in SBF of the Ti metals. This consistency could be interpreted in terms of cell response as follows. The Ti metal able to form the apatite on its surface in SBF forms the apatite on its surface soon after implanted into living body. Once the apatite is formed, osteogenic cells actively differentiate on its surface, as observed in culture experiments of rat bone marrow cells (Nishio et al., 2000) and of mouse calvaria osteoblast (Isaac et al., 2010) on a $\mathrm{NaOH}$ - and heat-treated Ti metal. Once the bone matrix is formed by the osteogenic cells, it can be tightly bonded to the apatite on the surface of the Ti metal, as observed for bone nodules, which was produced by cells migrated from the calvaria explant of rat, on a $\mathrm{NaOH}-$ and heat-treated Ti metal (Isaac et al., 2009). Recently, 


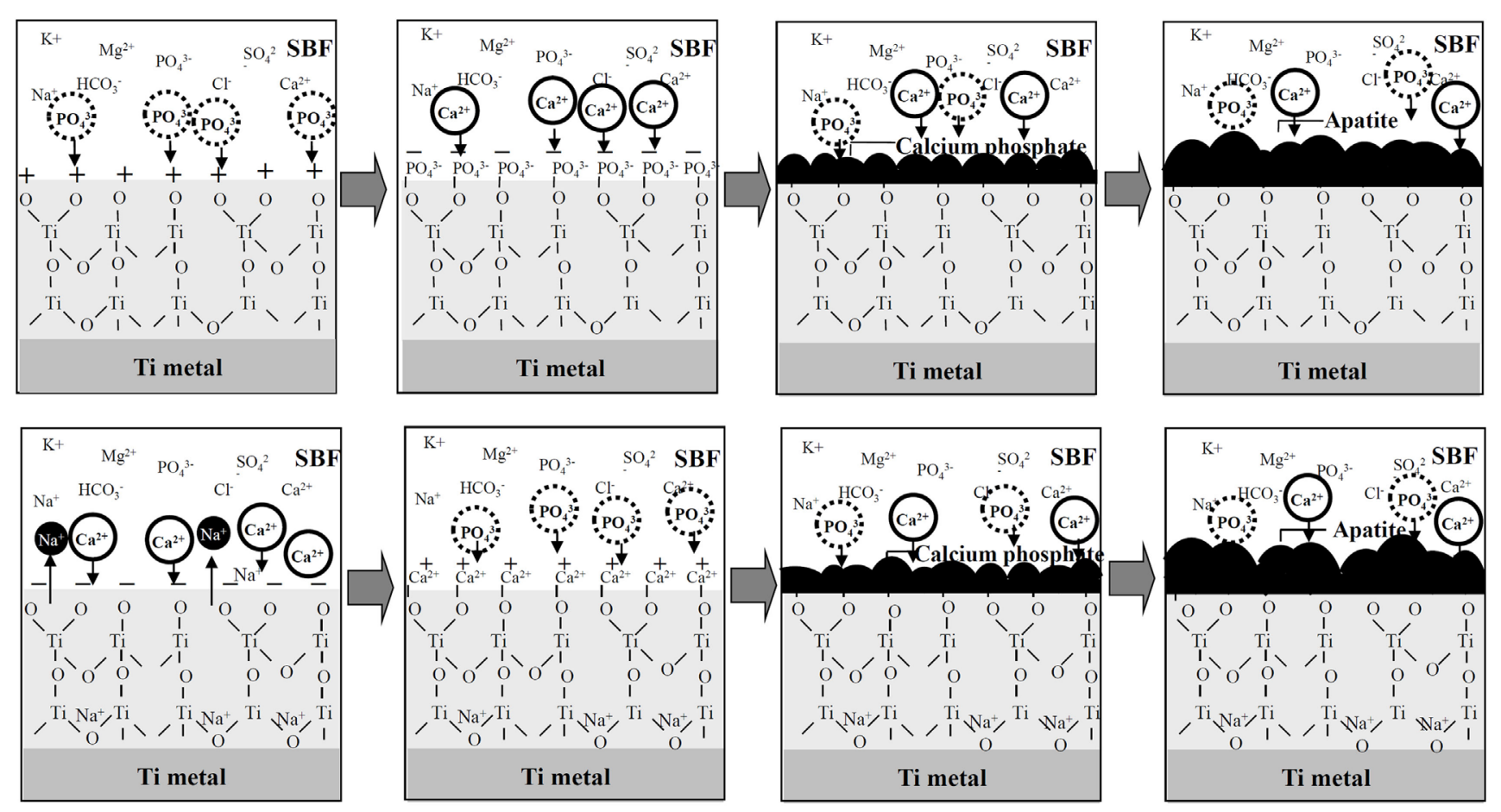

FIGURE 4 | Process of apatite formation on Ti metals heat-treated after exposure to strong acid solutions (top), and to strong alkali solutions (bottom). Reproduced from Pattanayak et al. (2012) with permission The Royal Society.
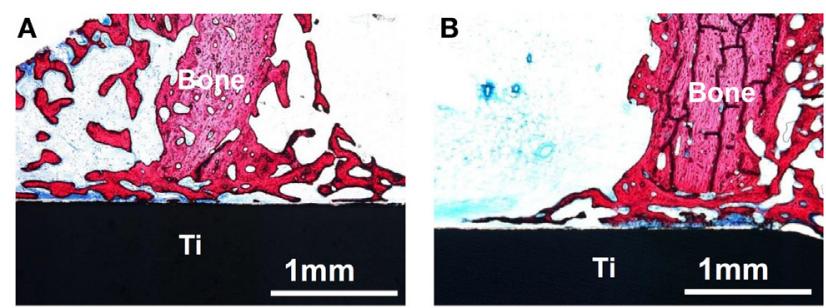

C
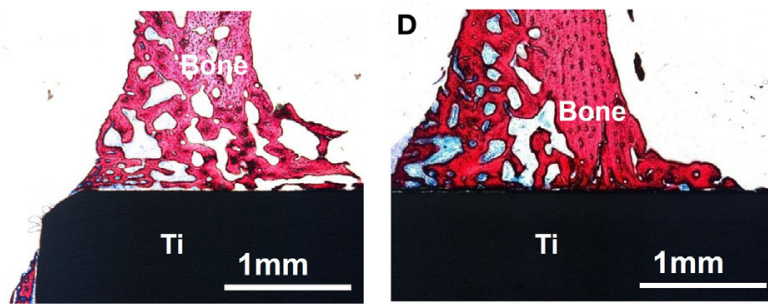

FIGURE 5 | Optical micrographs of non-decalcified sections of $\mathrm{Ti}$ metals subjected to no treatment (A), only $\mathrm{H}_{2} \mathrm{SO}_{4} / \mathrm{HCl}$ acid treatment (B), only heat treatment at $600^{\circ} \mathrm{C}$ (C) and $\mathrm{H}_{2} \mathrm{SO}_{4} / \mathrm{HCl}$ acid and heat treatment at $600^{\circ} \mathrm{C}(\mathrm{D}), 4$ weeks after implantation into the tibia of rabbit. Reproduced from Kawai et al. (2012) with permission Springer.

active proliferation and differentiation of osteoblast and multifocal nodule formation on the $\mathrm{NaOH}$ - and heat-treated $\mathrm{Ti}$ metal were observed for the Ti metal implanted into mouse by using fluorescent osteoblast in vivo (Tsukanaga et al., 2013).
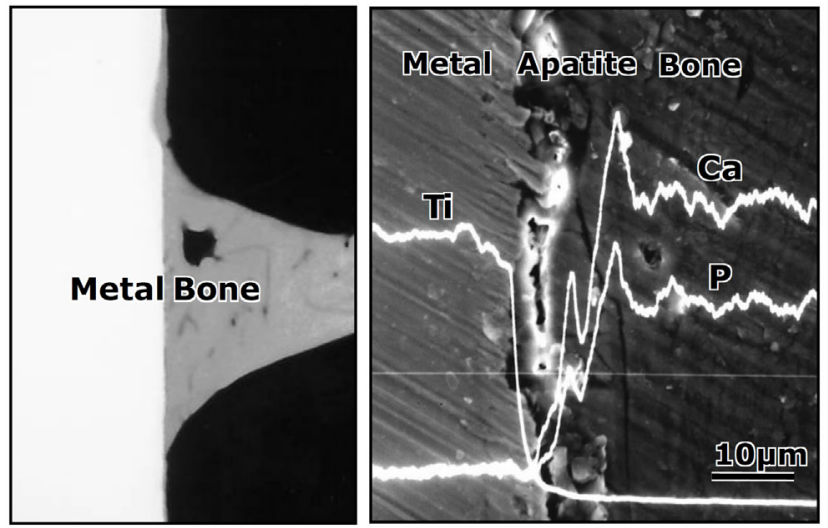

FIGURE 6 | Contact radiomicrograph (left hand) and SEM photograph (right hand) of Ti metal heat-treated after exposure to $\mathrm{NaOH}$ solution at its interface with the bone, 8 weeks after implantation into the tibia of rabbits. Reproduced from Yan et al. (1997) with permission John Willey and Sons.

It is apparent from these results that the natural Ti metal is unable to bond to living bone. When it is subjected to only the acid treatment or only the heat treatment, it also cannot bond to living bone (Kawai et al., 2012). However, it does bond to living bone, when it is heat-treated after exposure to strong acid or alkali solution so that a certain kind of thin ceramic layer is grown on its surface. 


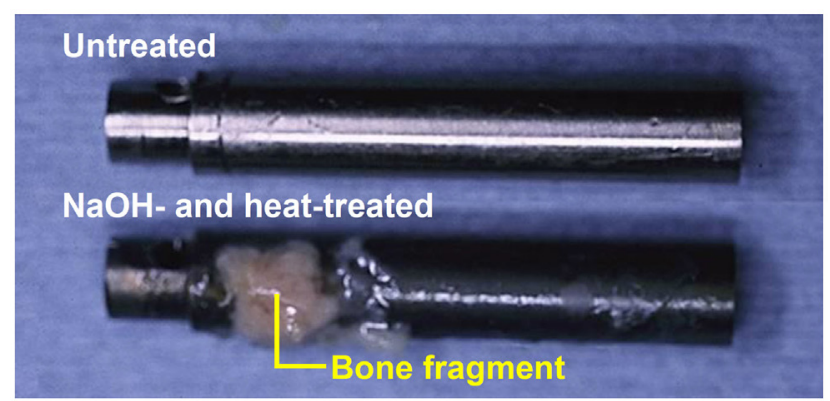

FIGURE 7 | Titanium metal rod untreated (top) and heat-treated after exposure to $\mathrm{NaOH}$ solution (bottom), both of which were pulled out after implanted into medullary canal of a rabbit for 12 weeks, after Nishiguchi et al. (2003).

\section{CLINICAL APPLICATIONS OF THE BONE-BONDING BIOACTIVE TI MEAL PREPARED BY SIMPLE CHEMICAL AND HEAT TREATMENTS}

It is well known that commercial dental implants may be subjected to $\mathrm{H}_{2} \mathrm{SO}_{4} / \mathrm{HCl}$ acid solution treatment in order to produce micrometer-scale roughness on their surface (Coelho et al., 2009). This treatment can promote mechanical interlocking of the dental implants with the surrounding bone. However, this treatment cannot make direct bonding of the dental implants to the surrounding bone.

The present result indicates that such implants can be induced to bond to bone when subjected to heat treatment after acid treatment, since a rutile layer capable of forming apatite in the living body is formed on its surface by the heat treatment. Such dental implants are expected to remain stably fixed over a long period of time after implantation.

It is expected that once a porous $\mathrm{Ti}$ metal layer has been produced on the surface of a Ti-based alloy, for example by a plasma spray method, and then subjected to the $\mathrm{NaOH}$ and heat treatments, such a medical device will be stably fixed to the surrounding bone, since the surrounding bone comes into direct contact with the porous Ti metal and grows into the pores (Kim et al., 2000c; Nishiguchi et al., 2001). Such a bone-bonding bioactive porous Ti metal layer was produced on the surface of accetabular shell and femoral stem of a total artificial hip joint made of Ti-6Al-2Nb-Ta alloy, as shown in Figure 8. This hip joint has been clinically used in more than 15,000 patients in Japan since 2007 (Kawanae et al., 2009). The result was confirmed by two implants retrieved 2 weeks and 8 years after implantation, respectively, due to femoral fracture and infection that the implant surface had become intimately integrated with newly grown bone as early as 2 weeks after implantation and had maintained this integrity for a minimum of 8 years (So et al., 2013).

Currently, hydroxyapatite is commonly coated on commercial artificial hip joints. For example, hydroxyapatite is coated by a flame-spray method on the rough Ti metal layer produced by the arc-spray method on the surface of the Ti-15Mo-5Zr-3Al alloy in one such case. Recently, Kawai et al. tried to apply the $\mathrm{NaOH}$ and heat treatments on the surface of the rough Ti metal layer produced on the Ti-5Mo-15Zr-3Al alloy by the arc-spray method for comparison. The rectangular plates subjected to the $\mathrm{NaOH}$ and heat treatments and hydroxyapatite coating, as well as that untreated were implanted into the tibia of a rabbit. Consequently, it was found that the bonding strength of the implants to the bone was not increased by the hydroxyapatite coating, but it was considerably increased by the $\mathrm{NaOH}$ and heat treatments as early as 4 weeks after implantation, and this increase was maintained even after 16 weeks. The lack of a positive effect of the hydroxyapatite coating was attributed to deterioration of the hydroxyapatite layer in the body (Kawai et al., 2015).

It is expected that this kind of simple chemical and heat treatment will also be useful for inducing bone-bonding bioactivity in different kinds of Ti metal implants in the orthopedic and dental fields. However, it will be ineffective for many kinds of Ti-based alloys. This treatment must be modified for such Ti-based alloys.

\section{MODIFICATION OF THE ALKALI AND HEAT TREATMENT}

Ti-based alloys such as Ti-6Al-4V, Ti-6Al-2Nb-Ta, and Ti-15Mo-5Zr-3Al exhibit much great mechanical strength and fracture toughness, and hence they are also widely used as implants in orthopedics and dentistry.

The simple heat treatment after exposure to the $\mathrm{NaOH}$ solution described above is also effective for these conventional Ti-based alloys in inducing bone-bonding bioactivity (Kim et al., 1996; Ueno et al., 2011). In these cases, alloying elements such as $\mathrm{Al}, \mathrm{V}$, and Mo are easily and selectively released during the $\mathrm{NaOH}$ treatment, and only the sodium titanate and rutile are precipitated on the surfaces of the alloys after the heat treatment, similar to the pure Ti metal (Kim et al., 1999; Kim et al., 2000a,b). Consequently, they come to exhibit the bone-bonding bioactivity as the result of this simple chemical and heat treatment (Nishiguchi et al., 1999).

On the other hand, Ti-based alloys in the system Ti-Zr-Nb$\mathrm{Ta}$, which are free of elements suspected of cytotoxicity such as $\mathrm{Al}$ and $\mathrm{V}$, were recently developed. Some of these alloys exhibit not only high mechanical strength, but also low elastic modulus close to that of human bone. They are thus expected to be more useful as implants in orthopedics and dentistry. However, the simple alkali and heat treatment is not effective for these alloys in inducing their bone-bonding bioactivity. The alloying elements such as $\mathrm{Zr}, \mathrm{Nb}$, and $\mathrm{Ta}$ are not as easily released as $\mathrm{Al}$ and $\mathrm{V}$ during the $\mathrm{NaOH}$ treatment, and considerable amounts of them remain even after the subsequent heat treatment, suppressing $\mathrm{Na}^{+}$ion release from the alloys and inhibiting apatite formation in SBF as well as in the body environment (Yamaguchi et al., 2011).

It is well known that $\mathrm{Ca}^{2+}$ ion release is more effective for apatite formation than $\mathrm{Na}^{+}$ion release. Therefore, it is expected that even these alloys could form the apatite on their surfaces in SBF as well as in the body environment if the sodium titanate on their surfaces were replaced with calcium titanate. However, calcium titanate cannot be formed by the simple chemical and heat 


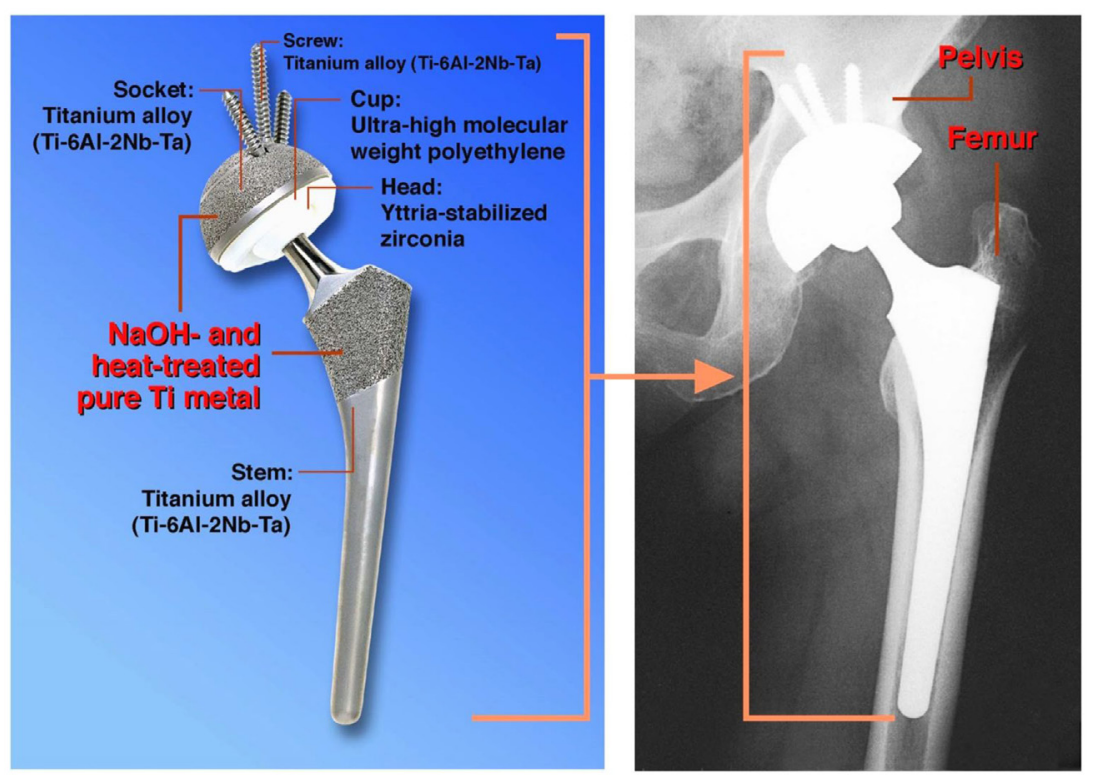

FIGURE 8 | Artificial hip joint, porous Ti metal layer of which was heat-treated after exposure to NaOH solution, after Kawanae et al. (2009).
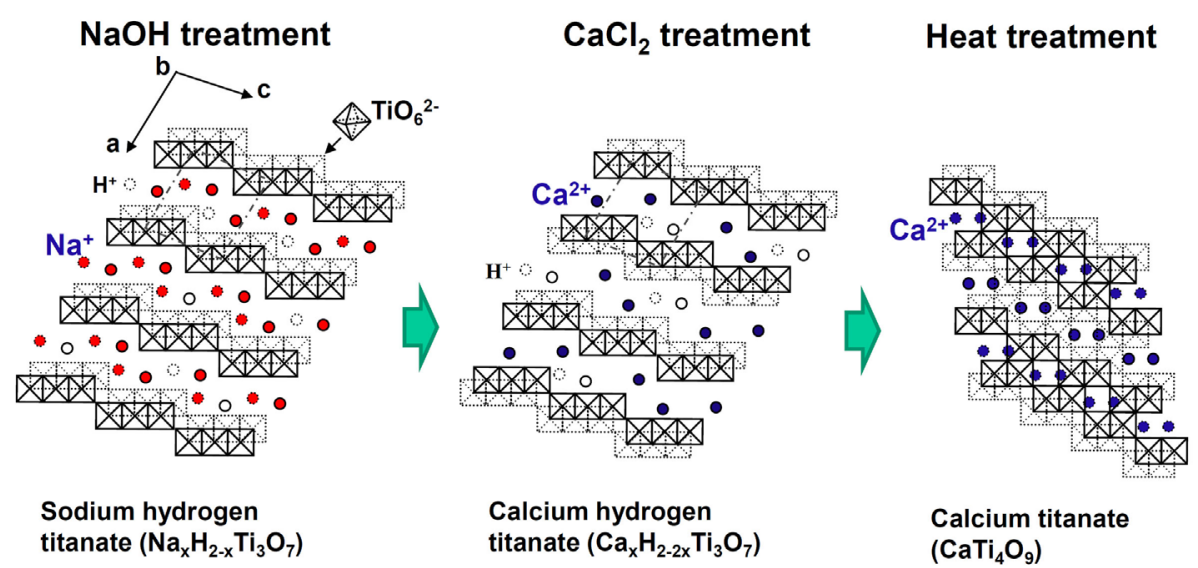

FIGURE 9 | Structures of sodium hydrogen titanate, calcium hydrogen titanate, and calcium titanate projected on a plane perpendicular to the crystallographic $\boldsymbol{b}$ axis. Reproduced from Kokubo and Yamaguchi (2015) with permission Elsevier.

treatment in which the $\mathrm{NaOH}$ solution is replaced by $\mathrm{Ca}(\mathrm{OH})_{2}$ solution, since the solubility of $\mathrm{Ca}(\mathrm{OH})_{2}$ in water is very low.

Fortunately, the sodium hydrogen titanate that forms on the Ti metal and its alloys by $\mathrm{NaOH}$ treatment has a well-developed layered structure, as shown in Figure 9 (Kokubo and Yamaguchi, 2015). It is expected that the $\mathrm{Na}^{+}$ions in the layered structure may be completely replaced with the $\mathrm{Ca}^{2+}$ ions in the $\mathrm{CaCl}_{2}$ solution to form a calcium hydrogen titanate. This phase might be transformed into calcium titanate by the subsequent heat treatment. When the Ti metal and its alloys were heat-treated after exposure to the $\mathrm{NaOH}$ and subsequent exposure to $100 \mathrm{mM}$ $\mathrm{CaCl}_{2}$ solution at $40^{\circ} \mathrm{C}$ for $24 \mathrm{~h}$, they formed the calcium titanate on their surfaces, as expected. However, the resulting products did not exhibit apatite formation on their surfaces in SBF. This was attributed to the extremely low release rate of the $\mathrm{Ca}^{2+}$ ions from the calcium titanate because of its dense structure (Kizuki et al., 2010).

Therefore, they were finally soaked in a hot water, in order to increase the release rate of the $\mathrm{Ca}^{2+}$ ions by partly replacing the $\mathrm{Ca}^{2+}$ ions at the surface of the calcium titanate with $\mathrm{H}_{3} \mathrm{O}^{+}$ions in the water, as shown in Figure 10 (Yamaguchi et al., 2010). As a result, the Ti-based alloys in the system $\mathrm{Ti}-\mathrm{Zr}-\mathrm{Nb}-\mathrm{Ta}$, as well as the pure Ti metal, formed the apatite on their surfaces in SBF (Kizuki et al., 2010; Yamaguchi et al., 2010, 2012).

When the Ti-based alloys as well as the pure Ti metal that had been subjected to this modified alkali and heat treatment 


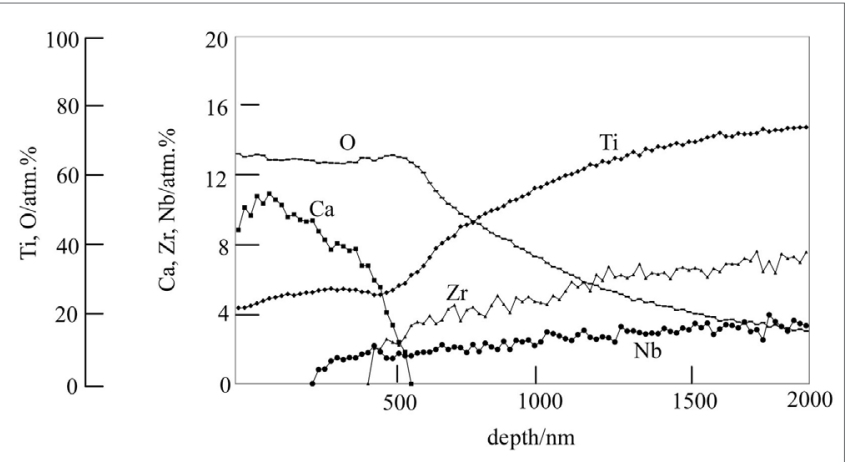

FIGURE 10 | Depth profile of Auger electron spectroscopy of the surface of $\mathrm{Ti}-15 \mathrm{Zr}-4 \mathrm{Nb}-4 \mathrm{Ta}$ alloy subjected to $\mathrm{NaOH}, \mathrm{CaCl}_{2}$, heat, and water treatments. Reproduced from Yamaguchi et al. (2010) with permission Springer.

for forming the Ca-deficient calcium titanate on their surfaces were implanted into the tibia of a rabbit, they came into direct contact with the surrounding bone without any intervention of fibrous tissue at their interface within 16 weeks (Fukuda et al., 2011a; Tanaka et al., 2014). When a tensile stress was applied to the interface of the $\mathrm{Ti}-15 \mathrm{Zr}-4 \mathrm{Nb}-4 \mathrm{Ta}$ alloy with the bone, the load required for producing the fracture was much higher for the alloy subjected to the modified alkali and heat treatment than the untreated alloy, as shown in Figure 11, and this difference increased with an increasing period of time after implantation (Fukuda et al., 2011a).

It should be noted here that this modified alkali and heat treatment that forms Ca-deficient calcium titanate has some advantages over the simple alkali and heat treatment not only for the alloys but also for pure Ti metal, in terms of insensibility to contamination of a $\mathrm{NaOH}$ reagent, and humidity in an environment. In general, even so-called high purity $\mathrm{NaOH}$ reagent contains small amount of the calcium ions as an impurity. The calcium ions are concentrated on the Ti metal surface during the course of $\mathrm{NaOH}$ solution treatment, to give calcium-contaminated sodium titanate after the heat treatment. The incorporated calcium ions suppress apatite formation of the surface of Ti metal in SBF as well as in the living body by inhibiting the $\mathrm{Na}^{+}$ions release, and hence decrease bone-bonding ability (Kizuki et al., 2013).

On the other hand, when the Ti metal and its alloys are stored in a humid environment, the $\mathrm{Na}^{+}$ions in the sodium titanate are liable to be released via exchange with the $\mathrm{H}_{3} \mathrm{O}^{+}$ions in the moisture, thus decreasing the $\mathrm{Na}^{+}$ions in the sodium titanate decreasing the bone-bonding ability (Kawai et al., 2010). Ti metal and its alloys subjected to the modified alkali and heat treatment so as to form the Ca-deficient calcium titanate on their surfaces have no such problems with regard to these matters.

\section{EXTENSION OF MODIFIED ALKALI AND HEAT TREATMENT}

Certain ions such as Mg (Park et al., 2012), Sr (Bonnelye et al., 2008), and Zn (Alvarez et al., 2010) are known to promote bone

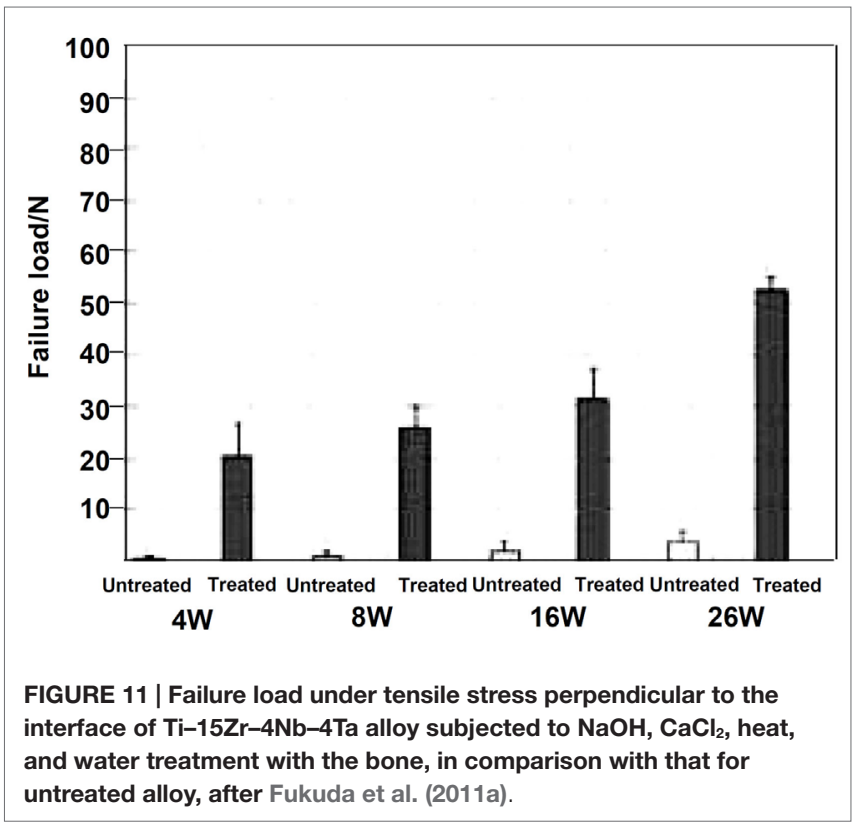

growth. It is expected that if these ions are slowly released from the bone-bonding bioactive Ti metal and its alloys, they can be bonded to the surrounding bone in a short period of time after implantation, since the surrounding bone grows to the apatite layer on the surface of the Ti metal in a short period. These ions can be incorporated into the Ca-deficient calcium titanate layer on the surface of the Ti metal and its alloys without disturbing their apatite-forming abilities by adding these ions into the $\mathrm{CaCl}_{2}$ solution of the second treatment, and/or into the hot water of the final treatment of the modified alkali and heat treatments (Yamaguchi et al., 2013a,b, 2014). For example, when the Ti metal is heat-treated at $600^{\circ} \mathrm{C}$ after exposure to a mixed solution of $50 \mathrm{ml} \mathrm{CaCl}_{2}$ and $50 \mathrm{ml} \mathrm{SrCl} 2$ at $40^{\circ} \mathrm{C}$ for $24 \mathrm{~h}$ following to the $\mathrm{NaOH}$ solution, and then soaked in $1 \mathrm{M} \mathrm{SrCl}_{2}$ solution at $80^{\circ} \mathrm{C}$ for $24 \mathrm{~h}$, the $\mathrm{Sr}^{2+}$ ions are incorporated into the $\mathrm{Ca}$-deficient calcium titanate, as shown by depth profile of XPS near the surface of the Ti metal in Figure 12 (Yamaguchi et al., 2014). It was confirmed that this Ti metal can form the apatite on its surface in SBF and that the $\mathrm{Sr}^{2+}$ ions are slowly released into the phosphate-buffered saline at $36.5^{\circ} \mathrm{C}$ (Yamaguchi et al., 2014).

The silver ion, which is known to exhibit antibacterial activity (Chen et al., 2008), also can be incorporated into the Ca-deficient calcium titanate layer of the Ti metal by replacing the final hot water of the modified alkali and heat treatment with $1 \mathrm{M} \mathrm{AgNO}_{3}$ solution (Kizuki et al., 2014). It was confirmed that this Ti metal also forms the apatite on its surface in SBF and that the $\mathrm{Ag}^{+}$ions are slowly released into fetal bovine serum. This Ti metal exhibited a strong antibacterial effect against Staphylococcus aureus, as expected (Kizuki et al., 2014).

It is apparent from these results that bone-bonding bioactive Ti metal and its alloys possessing various functions can be obtained by forming Ca-deficient calcium titanate containing various ions on their surfaces by the modified alkali and heat treatment. 


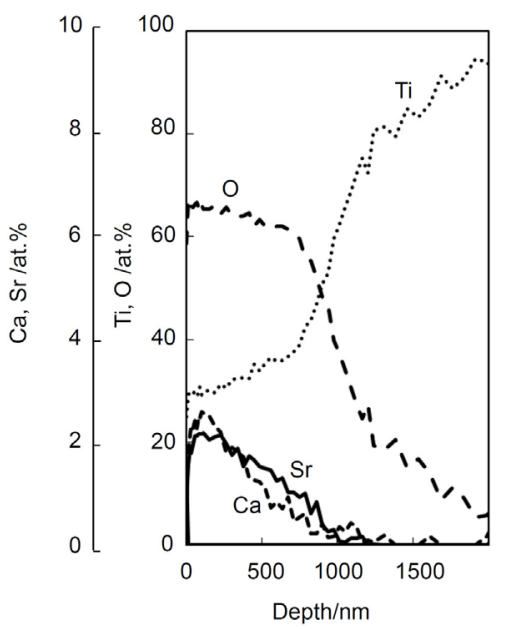

FIGURE 12 | Depth profile of XPS of Ti metal subjected to $\mathrm{NaOH}$, $\mathrm{CaCl}_{2} / \mathrm{SrCl}_{2}$, heat, and $\mathrm{SrCl}_{2}$ treatments. Reproduced from Yamaguchi et al. (2014) with permission Elsevier.

\section{MODIFICATION OF THE ACID AND HEAT TREATMENT}

The simple acid and heat treatment described above is not effective for many of the Ti-based alloys in inducing bone-bonding bioactivity, since the alloying elements are generally hardly released during the acid treatment and are enriched on the surface of the alloys during the subsequent heat treatment. For example, $\mathrm{Al}$ and $\mathrm{V}$ of the $\mathrm{Ti}-6 \mathrm{Al}-4 \mathrm{~V}$ alloy are hardly released during the first $\mathrm{H}_{2} \mathrm{SO}_{4} / \mathrm{HCl}$ acid treatment, and are segregated on the surface of the alloy during the subsequent heat treatment at $600^{\circ} \mathrm{C}$. Consequently, the Ti-6Al-4V alloy subjected to the simple acid and heat treatment does not form the apatite on its surface in SBF (Yamaguchi et al., 2015).

On the other hand, the alloying elements $\mathrm{Zr}, \mathrm{Nb}$, and $\mathrm{Ta}$ are generally more or less selectively released from the surface of the Ti-based alloys during the $\mathrm{NaOH}$ treatment. Therefore, if the Ti-based alloys are subjected to the acid and heat treatment after the $\mathrm{NaOH}$ treatment, they form titanium oxide on their surfaces to become able to form the apatite on their surfaces in SBF and the body environment. For example, if the $\mathrm{Ti}-15 \mathrm{Zr}-4 \mathrm{Nb}-4 \mathrm{~T}$ alloy is soaked in 0.5 or $50 \mathrm{mM} \mathrm{HCl}$ solution at $40^{\circ} \mathrm{C}$ for $24 \mathrm{~h}$ after the $\mathrm{NaOH}$ treatment and then subjected to heat treatment at $600^{\circ} \mathrm{C}$ for $1 \mathrm{~h}$, it forms anatase and rutile on its surface and exhibits apatite formation on its surface in SBF (Yamaguchi et al., 2011). The acid and heat treatment after the $\mathrm{NaOH}$ treatment gives stable apatite formation in SBF compared with the simple alkali and heat treatment, even in the case of pure Ti metal. Its apatite-forming ability increases with an increasing concentration of the acid solution (Pattanayak et al., 2009a, 2011a,b).

This modified acid and heat treatment as well as the simple acid and heat treatment are especially useful when they are applied to porous Ti metal.
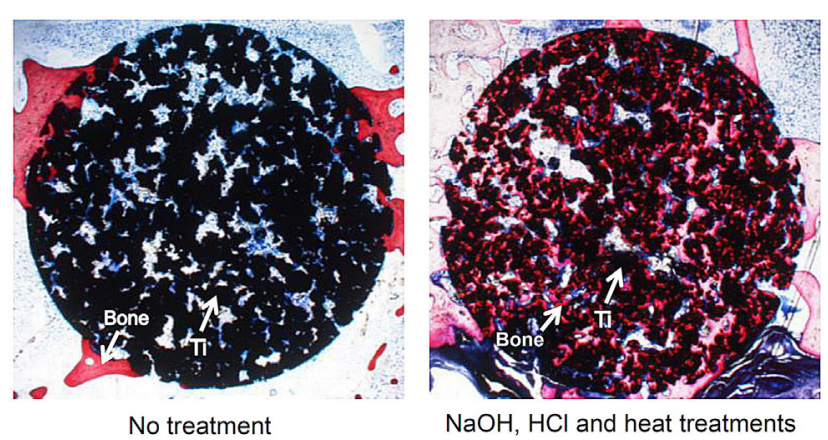

FIGURE 13 | Bone formation in porous Ti metals subjected to no treatment and $\mathrm{NaOH}, \mathrm{HCl}$, and heat treatments, 26 weeks after implantation into rabbit femur, after Takemoto et al. (2005) and Tanaka et al. (2009).

\section{APPLICATION OF THE ACID AND HEAT TREATMENT TO POROUS TI METAL}

Natural bone consists of a cancellous portion and a cortical portion. The cancellous portion consists of three dimensionally connected pores. If such a porous structure is introduced into the Ti metal, its elastic modulus can be decreased down to the level of human bone, making the Ti metal mechanically compatible with the surrounding bone. In addition, the Ti metal with such a porous structure can be easily fixed to the surrounding bone by bone ingrowth into the pores.

Ti metal with a porous structure that is well controlled in terms of the size and arrangement of the pores can be fabricated by sintering with metal powder containing volatile substances (Pattanayak et al., 2009b), as well as by 3D-printing methods such as a selective melting of the metal powders with a laser or electron beam (Pattanayak et al., 2011c and Fukuda et al., 2011b).

However, bone ingrowth into the pores is limited to only a shallow region of the porous structure for the naturally porous $\mathrm{Ti}$ metal, as shown in Figure 13 (Takemoto et al., 2005). In contrast, bone penetrates into a deeper region of the porous Ti metal subjected to the chemical and heat treatments for inducing the bone-bonding bioactivity described above, as shown in Figure 13 (Tanaka et al., 2009; Kawai et al., 2013).

It should be noted here that the bioactive porous Ti metal forms bone tissue in the porous structure not only in the bone defect, but also in muscle, as shown in Figure 14 (Fujibayashi et al., 2004; Takemoto et al., 2006). The former bone formation in bone defect is called osteoconduction, whereas the latter ectopic bone formation in muscle is called osteoinduction. It is interesting to note that the bioactive porous Ti metal forming the rutile on its surface by the simple (Kawai et al., 2014) or modified acid and heat treatment exhibit active osteoinductivity, while the bioactive porous Ti metal forming the sodium titanate or Ca-deficient calcium titanate on its surface by the simple or modified alkali and heat treatment exhibit only slight or no osteoinductivity. The latter poor osteoinductivity might be attributed to the adverse effect of the released $\mathrm{Na}^{+}$or $\mathrm{Ca}^{2+}$ ions on the activity of living cells in the narrow space of the pores by increasing the local $\mathrm{pH}$ in the environment. 


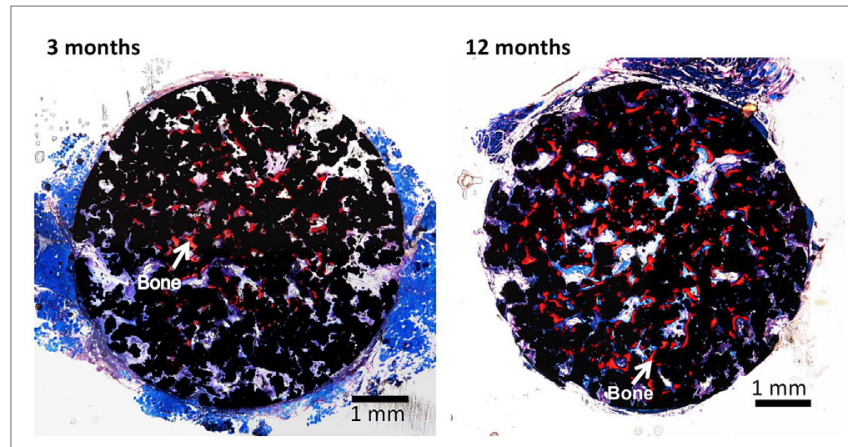

FIGURE 14 | Bone formation in porous Ti metals subjected to $\mathrm{NaOH}$, $\mathrm{HCl}$, and heat treatments, 3 and 12 months after implantation into muscle of beagle dog. Reproduced from Takemoto et al. (2006) with permission Elsevier.

It is expected that the osteoconductive and osteoinductive porous Ti metals prepared by the simple or modified acid and heat treatments will be used for various applications in orthopedics and dentistry.

\section{CLINICAL APPLICATIONS OF OSTEOCONDUCTIVE AND OSETEOINDUCTIVE POROUS TI METAL PREPARED BY ACID AND HEAT TREATMENT}

Porous $\mathrm{Ti}$ metals with a three-dimensional porous structure analogous to human cancellous bone are prepared by the sintering or 3D-printing of metal powders, as described above. They exhibit osteoconductivity as well as osteoinductivity when subjected to simple or modified acid and heat treatment. These porous Ti metals can be used as important bone substitutes in many applications.

For example, a porous $\mathrm{Ti}$ metal that is $50 \%$ in porosity and $300 \mu \mathrm{m}$ in average pore size prepared by the sintering method was subjected to $0.5 \mathrm{mM} \mathrm{HCl}$ and heat treatment after the $\mathrm{NaOH}$ treatment had formed anatase and rutile on its surface. It was implanted into a canine for spinal interbody fusion (Takemoto et al., 2007). Based on this successful result, it was subjected to clinical trials as a spinal fusion device in five human patients between November 2008 and June 2009, as shown in Figure 15 (Fujibayashi et al., 2011). Conventional spinal fusion devices need an autograft for fixation to the surrounding bone, since they cannot bond to living bone, whereas the present device can be fixed without an autograft, as it does bond to living bone. All of the clinical cases to date have resulted in a successful outcome.

\section{REFERENCES}

Alvarez, K., Fukuda, M., and Yamamoto, O. (2010). Titanium implants after alkali heating treatment with a $\left[\mathrm{Zn}(\mathrm{OH})_{4}\right]_{2}$-complex: analysis of interfacial bond strength using push-out tests. Clin. Implant Dent. Relat. Res. 12, e114-e125. doi:10.1111/j.1708-8208.2010.00278.x

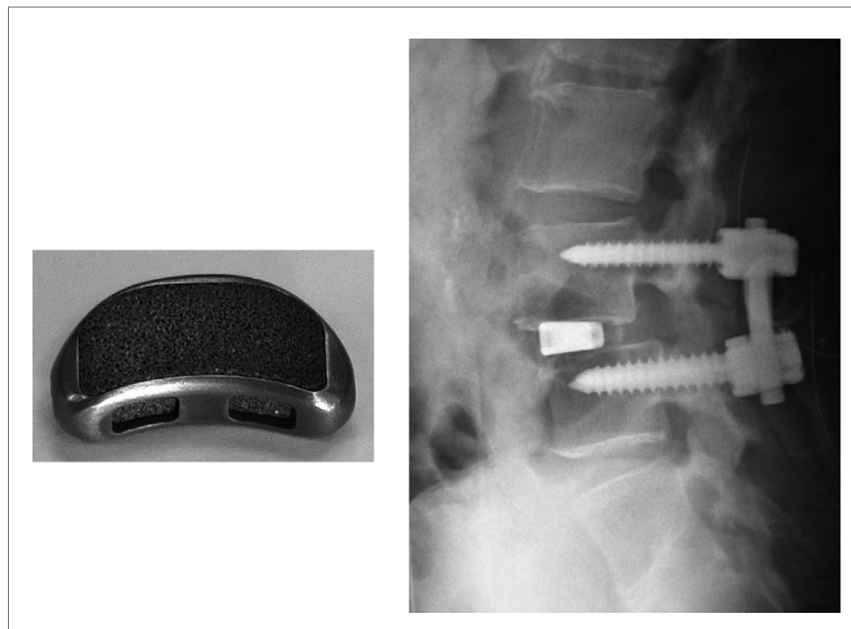

FIGURE 15 | Spinal fusion device of porous Ti metal subjected to $\mathrm{NaOH}, \mathrm{HCl}$ and heat treatments (left hand side) and its clinical application (right hand side). Reproduced from Fujibayashi et al. (2011) with permission Springer.

\section{CONCLUSION}

A positively charged titanium oxide layer was grown on Ti metal, when it was heat-treated after exposure to strong acid solution, whereas negatively charged sodium titanate layer was grown on Ti metal, when it was heat-treated after exposure to strong alkali solution. Both the resultant products formed an apatite on their surfaces in a SBF and bonded to the living bone in the rabbit tibia. The latter product was successfully clinically applied to artificial hip joint.

A negatively charged calcium-deficient calcium titanate layer was formed on $\mathrm{Ti}$ metal and its alloys, when they were heat-treated after exposure to $\mathrm{NaOH}$ and $\mathrm{CaCl}_{2}$ solutions and finally soaked in a hot water. They also formed the apatite on their surfaces in SBF and tightly bonded to the living bone. Bone growth promoting ions such as $\mathrm{Mg}, \mathrm{Sr}$, and $\mathrm{Zn}$, as well as antibacterial ions such as Ag were incorporated into the calcium titanate surface layers, in order to be slowly released in the living body.

Porous Ti metal grown with the positively charged titanium oxide on its surface exhibited not only osteoconduction but also osteoinduction. The resultant product is being subjected to clinical trials as a spinal fusion device.

This kind of novel bioactive materials exhibiting various kinds of biological functions as well as intrinsic high mechanical strength likely to play an increasingly more important role in repairing damaged bone tissues.

Armitage, D. A., Mihoc, R., Tate, T. J., McPhail, D. S., Chater, R., Hobkirk, J. A., et al (2007). The oxidation of calcium implanted titanium in water: a depth profiling study. Appl. Surf. Sci. 253, 4085-4093. doi:10.1016/j.apsusc.2006.09.006

Bjursten, L. M., Rasmusson, L., Oh, S., Smith, G. C., Brammer, K. S., and Jin, S. (2010). Titanium dioxide nanotubes enhance bone bonding in vivo. J. Biomed. Mater. Res. 92A, 1218-1224. doi:10.1002/jbm.a.32463 
Bonnelye, E., Chabadel, A., Saltel, F., and Jurdic, P. (2008). Dual effect of strontium ranelate: simulation of osteoblast differentiation and inhibition of osteoclast formation and resorption in vitro. Bone 42, 129-138. doi:10.1016/j. bone.2007.08.043

Chen, X.-B., Li, Y. C., Plessis, J. D., Hodgson, P. D., and Wen, C. (2009). Influence of calcium ion deposition on apatite-inducing ability of porous titanium for biomedical applications. Acta Biomater. 5, 1808-1820. doi:10.1016/j. actbio.2009.01.015

Chen, Y. K., Zheng, X. B., Xie, Y. T., Ding, C. X., Ruan, H. J., and Fan, C. Y. (2008). Anti-bacterial and cytotoxic properties of plasma sprayed silver-containing HA coating. J. Mater. Sci. Mater. Med. 19, 3603-3609. doi:10.1007/ s10856-008-3529-8

Coelho, P. G., Granjeiro, J. M., Romanos, G. E., Suzuki, M., Silva, N. R. F., Cardaropoli, G., et al. (2009). Basic research methods and current trends of dental implant surfaces. J. Biomed. Mater. Res. B Appl. Biomater 88B, 579-596. doi:10.1002/jbm.b.31264

Cooper, L. F., Zhou, Y., Takebe, J., Guo, J., Abron, A., Holmen, A., et al. (2006). Fluoride modification effects on osteoblast behavior and bone formation at $\mathrm{TiO}_{2}$ grit-blasted c.p. titanium endosseous implants. Biomaterials 27, 926-936. doi:10.1016/j.biomaterials.2005.07.009

Diefenback, M., Muckley, T., Shrader, C., Schmidt, J., Zankovych, S., Bossert, J., et al. (2011). The effect of plasma chemical oxidation of titanium alloy on bone-implant contact in rats. Biomaterials 32, 8041-8047. doi:10.1016/j. biomaterials.2011.07.046

Dong, W., Zhang, T., Epstein, J., Cooney, L., Wang, H., Li, Y., et al. (2007). Multifunctional nanowire bioscaffolds on titanium. Chem. Mater. 19, 4454-4459. doi:10.1021/cm070845a

Ferraris, S., Spriano, S., Pan, G., Venturello, A., Bianchi, C. L., Chiesa, R., et al. (2011). Surface modification of T-6Al-4V alloy for biomineralization and specific biological response: part 1, inorganic modification. J. Mater. Sci. Mater. Med. 22, 533-545. doi:10.1007/s10856-011-4246-2

Fujibayashi, S., Neo, M., Kim, H.-M., Kokubo, T., and Nakamura, T. (2004). Osteoinduction of porous bioactive titanium metal. Biomaterials 25, 443-450. doi:10.1016/S0142-9612(03)00551-9

Fujibayashi, S., Takemoto, M., Neo, M., Matsushita, T., Kokubo, T., Doi, K., et al. (2011). A novel synthetic material for spinal fusion: a prospective clinical trial of porous bioactive titanium metal for lumber interbody fusion. Eur. Spine J. 20, 1486-1495. doi:10.1007/s00586-011-1728-3

Fukuda, A., Takemoto, M., Saito, T., Fujibayashi, S., Neo, M., Yamaguchi, S., et al. (2011a). Bone bonding bioactivity of Ti metal and Ti-Zr-Nb-Ta alloys with $\mathrm{Ca}$ ions incorporated on their surfaces by simple chemical and heat treatments. Acta Biomater. 7, 1379-1386. doi:10.1016/j.actbio.2010.09.026

Fukuda, A., Takemoto, M., Saito, T., Fujibayashi, S., Neo, M., Pattanayak, D. K., et al. (2011b). Osteoinduction of porous Ti implants with a channel structure fabricated by selective laser melting. Acta Biomater. 7, 2327-2336. doi:10.1016/j. actbio.2011.01.037

Gold, J. M., Schmidt, M., and Steinmann, S. G. (1989). XPS study of amino acid adsorption to titanium surfaces. Helv. Phys. Acta 62, 246-249.

Hacking, S. A., Tanzer, M., Harvey, E. J., Krygier, J. J., and Bobyn, J. D. (2002). Relative contribution of chemistry and topography to the osseointegration oh hydroxyapatite coating. Clin. Orthop. Relat. Res. 405, 24-38. doi:10.1097/00003086-200212000-00004

Isaac, J., Galtayries, A., Kizuki, T., Kokubo, T., Berdal, A., and Sautier, J.-M. (2010). Bioengineered titanium surfaces affect the gene-expression and phenotypic response of oseteoprogenitor cells derived from mouse calvarial bones. Eur. Cell. Mater. 20, 178-196.

Isaac, J., Loty, S., Hamdan, A., Kokubo, T., Kim, H.-M., Berdal, A., et al. (2009). Bone-like tissue formation on a biomimetic titanium surface in an explant model of osteoconduction. J. Biomed. Mater. Res. 89A, 585-593. doi:10.1002/ jbm.a.31993

Karthega, M., and Rajendran, N. (2010). Hydrogen peroxide treatment on Ti-6Al-4V alloy: a promising surface modification technique for orthopaedic application. Appl. Surf. Sci. 256, 2176-2183. doi:10.1016/j.apsusc.2009.09.069

Kawai, T., Kizuki, T., Takadama, H., Matsushita, T., Unuma, T., Nakamura, T., et al. (2010). Apatite formation on surface titanate layer with different $\mathrm{Na}$ content on Ti metal. J. Ceram. Soc. Jpn. 118, 19-24. doi:10.2109/jcersj2.118.19

Kawai, T., Takemoto, M., Fujibayashi, S., Akiyama, H., Tanaka, S., Yamaguchi, S., et al. (2014). Osteoinduction on acid and heat treated porous Ti metal samples in canine muscle. PLoS ONE 9:e88366. doi:10.1371/journal.pone.0088366
Kawai, T., Takemoto, M., Fujibayashi, S., Akiyama, H., Yamaguchi, S., Pattanayak, D. K., et al. (2013). Osteoconduction of porous Ti metal enhanced by acid and heat treatments. J. Mater. Sci. Mater. Med. 24, 1701-1715. doi:10.1007/ s10856-013-4919-0

Kawai, T., Takemoto, M., Fujibayashi, S., Neo, M., Akiyama, H., Yamaguchi, S., et al. (2012). Bone-bonding properties of Ti metal subjected to acid and heat treatments. J. Mater. Sci. Mater. Med. 23, 2981-2992. doi:10.1007/ s10856-012-4758-4

Kawai, T., Takemoto, M., Fujibayashi, S., Tanaka, M., Akiyama, H., Nakamura, T., et al. (2015). Comparison between alkali heat treatment and sprayed hydroxyapatite coating on thermally-sprayed rough Ti surface in rabbit model: effects on bone bonding ability and osteoconductivity. J. Biomed. Mater. Res. B 103B, 1069-1081. doi:10.1002/jbm.b.33281

Kawanae, K., Ise, K., Goto, K., Akiyama, H., Nakamura, T., Kaneuji, A., et al. (2009). A new cementless total hip arthroplasty with bioactive titanium porous-coating by alkaline and heat treatments: average 4.8 -year results. J. Biomed. Mater. Res. B Appl. Biomater. 90B, 476-481. doi:10.1002/jbm.b.31309

Kim, H.-M., Himeno, T., Kawashita, M., Lee, J.-H., Kokubo, T., and Nakamura, T. (2003). Surface potential change in bioactive titanium metal during the process of apatite formation in simulated body fluid. J. Biomed. Mater. Res. A 67A, 1305-1309. doi:10.1002/jbm.a.20039

Kim,H.-M.,Miyaji,F.,Kokubo,T., andNakamura,T.(1996).PreparationofbioactiveTi and itsalloys via simple chemical surface treatment. J. Biomed.Mater. Res. 32, 409417.doi:10.1002/(SICI)1097-4636(199611)32:3<409::AID-JBM14>3.0.CO;2-B

Kim, H.-M., Miyaji, F., Kokubo, T., Nishiguchi, S., and Nakamura, T. (1999). Graded surface structure of bioactive titanium prepared by chemical treatment. J. Biomed. Mater. Res. 45, 100-107. doi:10.1002/ (SICI)1097-4636(199905)45:2<100::AID-JBM4>3.0.CO;2-0

Kim, H.-M., Takadama, H., Miyaji, F., Kokubo, T., Nishiguchi, S., and Nakamura, T. (2000a). Formation of bioactive functionally graded structure on Ti-6Al-4V alloy by chemical surface treatment. J. Mater. Sci. Mater. Med. 11, 555-559. doi:10.1023/A:1008924102096

Kim, H.-M., Takadama, H., Kokubo, T., Nishiguchi, S., and Nakamura, T. (2000b). Formation of bioactive graded surface structure on $\mathrm{Ti}-15 \mathrm{Mo}-5 \mathrm{Zr}$ $3 \mathrm{Al}$ alloys by chemical treatment. Biomaterials 21, 353-358. doi:10.1016/ S0142-9612(99)00190-8

Kim, H.-M., Kokubo, T., Fujibayashi, S., Nishiguchi, S., and Nakamura, T. (2000c). Bioactive macroporous titanium layer on titanium substrate. J. Biomed. Mater. Res. 52, 553-557. doi:10.1002/1097-4636(20001205)52:3<553::AIDJBM14>3.0.CO;2-X

Kizuki, T., Matsushita, T., and Kokubo, T. (2014). Antibacterial and bioactive calcium titanate layers formed on Ti metal and its alloys. J. Mater. Sci. Mater. Med. 25, 1737-1746. doi:10.1007/s10856-014-5201-9

Kizuki, T., Takadama, H., Matsushita, T., Nakamura, T., and Kokubo, T. (2010). Preparation of bioactive Ti metal surface enriched with calcium ions by chemical treatment. Acta Biomater. 6, 2836-2842. doi:10.1016/j. actbio.2010.01.007

Kizuki, T., Takadama, H., Matsushita, T., Nakamura, T., and Kokubo, T. (2013). Effect of Ca contamination on apatite formation in a Ti metal subjected to $\mathrm{NaOH}$ and heat treatments. J. Mater. Sci. Mater. Med. 24, 635-644. doi:10.1007/ s10856-012-4837-6

Kokubo, T. (2008). Bioceramics and Their Clinical Applications. Cambridge: Woodhead.

Kokubo, T., Pattanayak, D. K., Yamaguchi, S., Takadama, H., Matsushita, T., Kawai, T., et al. (2010). Positively charged bioactive charged bioactive Ti metal prepared by simple chemical and heat treatments. J. R. Soc. Interface 7, S503-S513. doi:10.1098/rsif.2010.0129.focus

Kokubo, T., and Takadama, H. (2006). How useful is SBF in predicting in vivo bone bioactivity? Biomaterials 15, 2907-2915. doi:10.1016/j. biomaterials.2006.01.017

Kokubo, T., and Yamaguchi, S. (2015). "Biomimetic surface modification of metallic biomaterials," in Surface Coating and Modification of Metallic Biomaterials, ed. Wen C. (Cambridge: Woodhead), 219-246.

Lee, M.-H., Park, H.-S., Min, K.-S., Ahn, S.-G., Park, J.-M., Song, K.-Y., et al. (2007). Evaluation of in vitro tests for surface-modified titanium by $\mathrm{H}_{2} \mathrm{SO}_{4}$ and $\mathrm{H}_{2} \mathrm{O}_{2}$ treatment. Met. Mater. Int. 13, 109-115. doi:10.1007/BF03027560

Leeuwenburgh, S. C. G., Wolke, J. G. C., Jansen, J. A., and de Groot, K. (2008). "Calcium phosphate coatings," in Bioceramics and Their Clinical Applications, ed. Kokubo T. (Cambridge: Woodhead), 464-484. 
Li, P., Ohtsuki, C., Kokubo, T., Nakanishi, K., Soga, N., and de Groot, K. (1994). The role of hydrated silica, titania, and alumina in inducing apatite on implants. J. Biomed. Mater. Res. 28, 7-15. doi:10.1002/jbm.820280103

Li, Y., Zou, S., Wang, D., Feng, G., Bao, C., and Hu, J. (2010). The effect of hydrofluoric acid treatment on titanium implant osseointegration in ovariecomized rats. Biomaterials 31, 3266-3273. doi:10.1016/j.biomaterials.2010.01.028

Liu, X., Zhao, Z., and Leng, Y. (2007). Biomimetic calcium phosphate coatings on nitric-acid-treated titanium surfaces. Mater. Sci. Eng. C 27, 700-708. doi:10.1016/j.msec.2006.06.030

Minagar, S., Wang, J., Barndt, C. C., Ivanova, E. P., and Wen, C. (2013). Cell response of anodized nanotubes on titanium and titanium alloys. J. Biomed. Mater. Res. A 101A, 2726-2739. doi:10.1002/jbm.a.34575

Nayab, S.N., Jones, F. H., and Olsen, I. (2007). Enhancement of Effects of calcium ion-implantation of titanium on bone cell function in vitro. J. Biomed. Mater. Res. A 83A, 292-302. doi:10.1002/jbm.a.31218

Nishiguchi, S., Fujibayashi, S., Kim, H. -M., Kokubo, T., and Nakamura, T. (2003). Biology of alkali- and heat-treated titanium implants. J. Biomed. Mater. Res. A 67A, 26-35. doi:10.1002/jbm.a.10540

Nishiguchi, S., Kato, H., Fujita, H., Kim, H.-M., Miyaji, F., Kokubo, T., et al. (1999). Enhancement of Bone-bonding strengths of titanium alloy implants by alkali and heat treatments. J. Biomed. Mater. Res. (Appl. Biomater.) 48, 689-696. doi:10.1002/(SICI)1097-4636(1999)48:5<689::AID-JBM13>3.0.CO;2-C

Nishiguchi, S., Kato, H., Fujita, H., Oka, M., Kim, H.-M., Kokubo, T., et al. (2001). Titanium metals form direct bonding to bone after alkali and heat treatments. Biomaterials 22, 2525-2533. doi:10.1016/S0142-9612(00)00443-9

Nishio, K., Neo, M., Akiyama, H., Nishiguchi, S., Kim, H.-M., Kokubo, T., etal. (2000). The effect of alkali- and heat-treated titanium and apatite-formed titanium on osteoblastic differentiation of bone marrow cells. J. Biomed. Mater. Res. 52, 652661. doi:10.1002/1097-4636(20001215)52:4<652::AID-JBM9>3.0.CO;2-W

Park, J. B., and Lakes, R. S. (1992). Biomaterials, An Itroduction, Second Edn. New York, NY: Plenam, 231-236.

Park, J.-W., Kim, Y.-J., Jang, J.-H., Kwon, T. G., Bae, Y.-C., and Suh, J.-Y. (2010). Effects of phosphoric acid treatment of titanium surface on surface properties, osteoblast response and removal of torque forces. Acta Biomater. 6, 1661-1670. doi:10.1016/j.actbio.2009.10.011

Park, J.-W., Ko, H.-J., Jang, J.-H., Kang, H., and Suh, J.-Y. (2012). Increased new bone formation with a surface magnesium-incorporated deproteinized porcine bone substitute in rabbit calvarial defects. J. Biomed. Mater. Res. A 100A, 834-840. doi:10.1002/jbm.a.34017

Park, J.-W., Park, K. B., and Suh, J.-Y. (2007). Effects of calcium ion incorporation on bone healing of Ti6Al4V alloy implants in rabbit tibia. Biomaterials 28, 3306-3313. doi:10.1016/j.biomaterials.2007.04.007

Pattanayak, D. K., Kawai, T., Matsushita, T., Takadama, H., Nakamura, T., and Kokubo, T. (2009a). Effect of $\mathrm{HCl}$ concentrations on apatite-forming ability of $\mathrm{NaOH}-\mathrm{HCl}$-and heat-treated titanium metal. J. Mater. Sci. Mater. Med. 20, 2401-2411. doi:10.1007/s10856-009-3815-0

Pattanayak, D. K., Matsushita, T., Doi, K., Takadama, H., Nakamura, T., and Kokubo, T. (2009b). Efect of oxygen content of porous titanium metal on its apatite-forming ability and compressice strength. Mater. Sci. Eng. C 29, 1974-1978. doi:10.1016/j.msec.2009.03.014

Pattanayak, D. K., Yamaguchi, S., Matsushita, T., and Kokubo, T. (2011a). Effect of heat treatments on apatite-forming ability of $\mathrm{NaOH}$-and $\mathrm{HCl}$-treated titanium metal. J. Mater. Sci. Mater. Med. 22, 273-278. doi:10.1007/s10856-010-4218-y

Pattanayak, D. K., Yamaguchi, S., Matsushita, T., and Kokubo, T. (2011b). Nanostructured positively charged bioactive $\mathrm{TiO}_{2}$ layer formed on $\mathrm{Ti}$ metal by $\mathrm{NaOH}$, acid and heat treatments. J. Mater. Sci. Mater. Med. 22, 1803-1812. doi:10.1007/s10856-011-4372-x

Pattanayak, D. K., Fukuda, A., Matsushita, T., Takemoto, M., Fujibayashi, S., and Sasaki, K. (2011c). Bioactive Ti metal analogous to human cancellous bone: fabrication by selective laser melting and chemical treatments. Acta Biomater. 7, 1398-1406. doi:10.1016/j.actbio.2010.09.034

Pattanayak, D. K., Yamaguchi, S., Matsushita, T., Nakamura, T., and Kokubo, T. (2012). Apatite-forming ability of titanium in terms of $\mathrm{pH}$ of the exposed solution. J. R. Soc. Interface 9, 2145-2155. doi:10.1098/rsif.2012.0107

Rautray, T. R., Narayanan, R., Kwon, T.-Y., and Kim, K.-H. (2010). Surface modification of titanium and titanium alloys by ion implantation. J. Biomed. Mater. Res. B Appl. Biomater. 93B, 581-591. doi:10.1002/jbm.b.31596

Shibata, Y., Suzuki, D., Omori, S., Tanaka, R., Murakami, A., Kataoka, Y., et al. (2010). The characteristics of in vitro biological activity of titanium surfaces anodically oxidized in chloride solution. Biomaterials 31, 8546-8555. doi:10.1016/j.biomaterials.2010.07.098

So, K., Kaneuji, A., Matsumoto, T., Matsuda, S., and Akiyama, H. (2013). Is the bone-bonding ability of a cementless total hip prosthesis enhanced by alkaline and heat treatments. Clin. Orthop. Relat. Res. 471, 3847-3855. doi:10.1007/ s11999-013-2945-3

Sugino, A., Ohtsuki, C., Tsuru, K., Hayakawa, S., Nakano, T., Okazaki, Y., et al. (2009). Effect of spatial design and thermal oxidation on apatite formation on Ti-15Zr-4Ta-4Nb alloy. Acta Biomater. 5, 298-304. doi:10.1016/j. actbio.2008.07.014

Suh, Y.-T. (2003). The significance of the surface properties of oxidized titanium to the bone response: special emphasis on potential biochemical bonding of oxidized titanium implant. Biomaterials 24, 3893-3907. doi:10.1016/ S0142-9612(03)00261-8

Taguchi, T., Muraoka, Y., Matasuyama, H., and Akashi, M. (2001). Apatite coating on hydrophilic polymer-grafted poly(ethylene) films using an alternative soaking process. Biomaterials 22, 53-58. doi:10.1016/S0142-9612(00)00162-9

Takadama, H., Kim, H.-M., Kokubo, T., and Nakamura, T. (2001a). An $\mathrm{X}$-ray photoelectron spectroscopy study of the process of apatite formation on bioactive titanium metal. J. Biomed. Mater. Res. 55, 185-193. doi:10.1002/1097-4636(200105)55:2<185::AID-JBM1005>3.0.CO;2-P

Takadama, H., Kim, H.-M., Kokubo, T., and Nakamura, T. (2001b). TEMEDX study of mechanism of bonelike apatite formation on bioactive titanium metal in simulated body fluid. J. Biomed. Mater. Res. 57, 441-448. doi:10.1002/1097-4636(20011205)57:3<441::AID-JBM1187>3.0.CO;2-B

Takemoto, M., Fujibayashi, S., Neo, M., So, K., Akiyama, N., Matsushita, T., et al. (2007). A porous bioactive titanium implant for spinal interbody fusion: an experimental study using a canine model. J. Neurosurg. Spine 7, 435-443. doi:10.3171/SPI-07/10/435

Takemoto, M., Fujibayashi, S., Neo, M., Suzuki, J., Kokubo, T., and Nakamura, T. (2005). Mechanical properties and osteoconductivity of porous bioactive titanium. Biomaterials 26, 6014-6023. doi:10.1016/j. biomaterials.2005.03.019

Takemoto, M., Fujibayashi, S., Neo, M., Suzuki, J., Matsushita, T., Kokubo, T., et al. (2006). Osteoinductive porous titanium implants: effect of sodium removal by dilute $\mathrm{HCl}$ treatment. Biomaterials 27, 2682-2691. doi:10.1016/j. biomaterials.2005.12.014

Takeuchi, K., Saruwatari, L., Nakamura, H., Yang, J.-M., and Ogawa, T. (2005). Enhanced intrinsic biomechanical properties of osteoblastic mineralized tissue on roughened titanium surface. J. Biomed. Mater. Res. A 72A, 296-305. doi:10.1002/jbm.a.30227

Tanaka, K., Takemoto, M., Fujibayashi, S., Kawanabe, K., Matsushita, T., Kokubo, T., et al. (2009). Long term study of osteoconductivity of bioactive porous titanium metals: effects of sodium removal by dilute $\mathrm{HCl}$ treatment. Key Eng. Mater. 396-398, 353-356. doi:10.4028/www.scientific.net/ KEM.396-398.353

Tanaka, M., Takemoto, M., Fujibayashi, S., Kawai, T., Yamaguchi, S., Kizuki, T., et al. (2014). Bone bonding ability of a chemically treated low elastic modulus Ti alloy; gum metal. J. Mater. Sci. Mater. Med. 25, 635-643. doi:10.1007/ s10856-013-5101-4

Tsukanaga, M., Yamamoto, K., Fujibayashi, S., Pattanayak, D. K., Matsushita, T., Kokubo, T., et al. (2013). Evaluation of bioactivity of alkali- and heat-treated titanium using fluorescent mouse osteoblasts. J. Bone Miner. Metab. 32, 660-670. doi:10.1007/s00774-013-0544-8

Turkan, U., and Guden, M. (2010). The effect of nitiric acid surface treatment on CaP deposition on Ti6Al4V open-cell foams in SBF solution. Surf. Coat. Technol. 205, 1904-1916. doi:10.1016/j.surfcoat.2010.08.071

Ueda, M., Ikeda, M., and Ogawa, M. (2009). Chemical-hydrothermal combined surface modification of titanium for improvement of osteointegration. Mater. Sci. Eng. C 29, 994-1000. doi:10.1016/j.msec.2008.09.002

Ueno, T., Tsukimura, N., Yamada, M., and Ogawa, T. (2011). Enhanced bone-integration capability of alkali-and heat-treated nanopolymorphic titanium in micro-to-nanoscale hierarchy. Biomaterials 32, 7297-7308. doi:10.1016/j. biomaterials.2011.06.033

Wang, X.-X., Hayakawa, S., Tsuru, K., and Osaka, A. (2002). Bioactive titania gel layers formed by chemical treatment of Ti substrate with $\mathrm{H}_{2} \mathrm{O}_{2} / \mathrm{HCl}$ solution. Biomaterials 23, 1353-1357. doi:10.1016/S0142-9612(01)00254-X

Whiteside, P., Matykina, E., Gough, J. E., Skeldon, P., and Thompson, G. E. (2010). In vitro evaluation of cell proliferation and collagen synthesis on titanium 
following plasma electrolytic oxidation. J. Biomed. Mater. Res. A 94A, 38-46. doi:10.1002/jbm.a.32664

Wu, J.-M., Hayakawa, S., Tsuru, K., and Osaka, A. (2004). Low-temperature preparation of anatase and rutile layers on titanium substrates and their ability to induce vitro apatite deposition. J. Am. Ceram. Soc. 87, 1635-1642. doi:10.1111/j.1551-2916.2004.01635.x

Xie, L., Liao, X., Yin, G., Huang, Z., Yan, D., Yao, D., et al. (2011). Preparation, characterization, in vitro bioactivity, and osteoblast adhesion of multi-level porous titania layer on titanium by two-step anodization treatment. J. Biomed. Mater. Res. A 98A, 312-320. doi:10.1002/jbm.a.33120

Yamaguchi, S., Akeda, K., Murata, K., Takegami, N., Goto, M., Sudo, A., et al. (2015). Chemical and heat treatments for inducing bone-bonding ability of Ti-6Al-4V pedicle screw. Key Eng. Mater. 631, 225-230. doi:10.4028/www. scientific.net/KEM.631.225

Yamaguchi, S., Kizuki, T., Takadama, H., Matsushita, T., Nakamura, T., and Kokubo, T. (2012). Formation of a bioactive calcium titanate layer on gum metal by chemical treatment. J. Mater. Sci. Mater. Med. 23, 873-883. doi:10.1007/ s10856-012-4569-7

Yamaguchi, S., Matsushita, T., and Kokubo, T. (2013a). A bioactive Ti metal with a Ca-enriched surface layer releases Mg ions. RSC Adv. 3, 11274-11282. doi:10.1039/c3ra00054k

Yamaguchi, S., Matsushita, T., Nakamura, T., and Kokubo, T. (2013b). Bioactive Ti metal with Ca-enriched surface layer able to release $\mathrm{Zn}$ ion. Key Eng. Mater. 52, 547-552. doi:10.4028/www.scientific.net/KEM.529-530.547

Yamaguchi, S., Nath, S., Matsushita, T., and Kokubo, T. (2014). Controlled release of strontium ions from a bioactive Ti metal with a Ca-enriched surface layer. Acta Biomater. 10, 2282-2289. doi:10.1016/j. actbio.2014.01.026

Yamaguchi, S., Takadama, H., Matsushita, T., Nakamura, T., and Kokubo, T. (2009). Cross-sectional analysis of the surface ceramic layer developed on Ti metal by $\mathrm{NaOH}$-heat treatment and soaking in SBF. J. Ceram. Soc. Jpn. 117, 1126-1130. doi:10.2109/jcersj2.117.1126

Yamaguchi, S., Takadama, H., Matsushita, T., Nakamura, T., and Kokubo, T. (2010). Apatite-forming ability of Ti-15Zr-4Nb-4Ta alloy induced by calcium solution treatment. J. Mater. Sci. Mater. Med. 21, 439-444. doi:10.1007/ s10856-009-3904-0

Yamaguchi, S., Takadama, H., Matsushita, T., Nakamura, T., and Kokubo, T. (2011). Preparation of bioactive Ti-15Zr-4Nb-4Ta alloy from $\mathrm{HCl}$ and heat treatments after an $\mathrm{NaOH}$ treatment. J. Biomed. Mater. Res. A 97A, 135-144. doi:10.1002/ jbm.a.33036
Yan, W.-Q., Nakamura, T., Kobayashi, M., Kim, H.-M., Miyaji, F., and Kokubo, T. (1997). Bonding of chemically treated titanium implants to bone. J.Biomed. Mater. Res. 37, 267-275. doi:10.1002/ (SICI) 1097-4636(199711)37:2<267::AID-JBM17>3.0.CO;2-B

Zhang, L., Ayukawa, Y., LeGeros, R. Z., Matsuya, S., Koyano, K., and Ishikawa, K. (2010). Tissue-response to calcium-bonded titanium surface. J. Biomed. Mater. Res. A 95A, 33-39. doi:10.1002/jbm.a.32763

Zhang, P., Zhang, Z., Li, W., and Zhu, M. (2013). Effect of Ti-OH groups on microstructure and bioactivity of $\mathrm{TiO}_{2}$ coating prepared by micro-ark oxidation. Appl. Surf. Sci. 268, 381-386. doi:10.1016/j.apsusc.2013.09.163

Zhao, L., Mei, S., Chu, P. K., Zhang, Y., and Wu, Z. (2010). The influence of hierarchical hybrid micro/nano-textured titanium surface with titania nanotubes on osteoblast functions. Biomaterials 31, 5072-5082. doi:10.1016/j. biomaterials.2010.03.014

Zhao, X., Liu, X., and Ding, C. (2005). Acid-induced bioactive titania surface. J. Biomed. Mater. Res. A 75A, 888-894. doi:10.1002/jbm.a.30485

Zhao, X., Liu, X., You, J., Chen, Z., and Ding, C. (2008). Bioactivity and cytocompatibility of plasma-sprayed titania coating treated by sulfuric acid treatment. Surf. Coat. Technol. 202, 3221-3226. doi:10.1016/j.surfcoat.2007. 11.026

Zhou, R., Wei, D., Yang, H., Cheng, S., Feng, W., Li, B., et al. (2014). Osseointegration of bioactive microarc oxidized amorphous phase/ $/ \mathrm{TiO}_{2}$ nanocrystals composite coatings on titanium after implantation into rabbit tibia. Mater. Sci. Mater. Med. 25, 1307-1318. doi:10.1007/s10856-014-5154-Z

Zhou, W., Zhou, X., Wu, X., Yuan, L., Shu, Q., Xia, Y., et al. (2007). Plasma-controlled nanocrystallinity and phase composition of $\mathrm{TiO}_{2}$ : a smart way to enhance biomimetic response. J. Biomed. Mater. Res. A 81A, 453-464. doi:10.1002/ jbm.a.30987

Conflict of Interest Statement: The authors declare that the research was conducted in the absence of any commercial or financial relationships that could be construed as a potential conflict of interest.

Copyright $\odot 2015$ Kokubo and Yamaguchi. This is an open-access article distributed under the terms of the Creative Commons Attribution License (CC BY). The use, distribution or reproduction in other forums is permitted, provided the original author(s) or licensor are credited and that the original publication in this journal is cited, in accordance with accepted academic practice. No use, distribution or reproduction is permitted which does not comply with these terms. 